\title{
Diel horizontal distribution of microcrustaceans and predators throughout a year in a shallow neotropical lake
}

\author{
Arcifa, MS. *, Bunioto, TC., Perticarrari, A. and Minto, WJ. \\ Departamento de Biologia, Faculdade de Filosofia, Ciências e Letras de Ribeirão Preto, \\ Universidade de São Paulo - USP, Av. Bandeirantes, 3900, CEP 14040-901, Ribeirão Preto, SP, Brazil \\ *e-mail: marcifa@usp.br
}

Received January 31, 2012 - Accepted April 2, 2012 - Distributed February 28, 2013

(With 7 figures)

\begin{abstract}
The focus of this study is to investigate if microcrustaceans undergo diel horizontal migration (DHM) in a tropical shallow lake on a yearly basis and analyse the adaptive value regarding predation. Abundance of invertebrate predators, chaoborid larvae and water mites, and microcrustaceans (cladocerans and copepods) were evaluated on a monthly basis in three stations located on a transect during the day and at night. Both invertebrate predators were predominantly pelagic. Cladocerans did not undergo significant DHM, distributing indistinctly onshore and offshore or being mostly pelagic. Nauplii, copepodites of two copepod species and adults of Tropocyclops prasinus meridionalis Kiefer were mostly distributed offshore, and did not perform DHM. The limnological features (temperature, dissolved oxygen, $\mathrm{pH}$, and conductivity) were suitable for the organisms in both zones of the lake. Algal food concentration was a little lower in the littoral than in the limnetic zone during the day, but it seems to be suitable for the organisms. However, as the algae quality was not evaluated, it is not possible to be conclusive concerning its influence. The results indicated that DHM was not performed by the microcrustaceans and is not, therefore, a strategy for decreasing predation by both invertebrates, Chaoborus brasiliensis Theobald and Krendowskia sp., on a yearly basis in this shallow lake.
\end{abstract}

Keywords: Chaoborus, water mites, cladocerans, copepods, food, DHM.

\section{Distribuição horizontal de microcrustáceos e predadores ao longo do ano em um lago neotropical}

\begin{abstract}
Resumo
O foco deste estudo é verificar se microcrustáceos apresentam migração horizontal diária (MHD) em um lago raso tropical, durante um ano, e o valor adaptativo com relação à predação. A abundância de predadores invertebrados, larvas de caoborídeos e ácaros aquáticos, e de cladóceros e copépodos foi avaliada mensalmente em três estações de coleta localizadas em um transecto, de dia e à noite. Ambos os predadores invertebrados foram predominantemente pelágicos. Os cladóceros não realizaram MHD, distribuindo-se indistintamente nas zonas litorânea e pelágica, ou foram mais abundantes na zona limnética. Os náuplios e copepoditos de duas espécies de copépodos e os adultos de Tropocyclops prasinus meridionalis Kiefer ocuparam principalmente a zona limnética, não migrando horizontalmente. As características limnológicas (temperatura, oxigênio dissolvido, $\mathrm{pH}$ e condutividade) foram adequadas nas duas zonas do lago. A concentração de alga foi um pouco menor no litoral do que na zona limnética durante o dia e parece ser adequada para os organismos; contudo, como a qualidade das algas não foi avaliada, não é possível ser conclusivo sobre sua influência. Os resultados indicaram que os microcrustáceos não realizaram MHD, a qual não constitui, portanto, uma estratégia para diminuir a predação dos dois invertebrados, Chaoborus brasiliensis Theobald e Krendowskia sp., em uma base anual, neste lago raso.
\end{abstract}

Palavras-chave: Chaoborus, ácaros aquáticos, cladóceros, copépodos, alimento, MHD. 


\section{Introduction}

In the last decades, diel horizontal migration (DHM) has been pointed out as an adaptive behavior of prey to escape from predators. Although several studies have dealt with DHM (e.g. Lauridsen and Buenk, 1996; Lauridsen et al., 1996; Burks et al., 2001, 2002), doubts still remain on the fitness of planktonic organisms to live within macrophyte stands. Macrophytes are believed to be a refuge of planktonic species for decreasing the predation risk, but the edge of macrophytes can also be a shelter for migratory planktonic cladocerans (Lauridsen and Buenk, 1996). A high macrophyte bed edge:area ratio is more suitable for planktonic cladocerans than a low ratio, which favors the macrophyte-associated species (Lauridsen et al., 1996), meaning that large macrophyte stands are not the most suitable place for planktonic microcrustaceans.

In the littoral zone, migratory organisms can be constrained by onshore predators and lower food quality (Smiley and Tessier, 1998; Wojtal et al., 2007; González Sagrario et al., 2009), by quality of refuges concerning the composition of macrophytes (Meerhoff et al., 2007), by unsuitable physical and chemical features, such as low dissolved oxygen within macrophyte stands (Miranda and Hodges, 2000). Actually, this habitat can even be avoided by some zooplanktonic organisms (Dorgelo and Heykoop, 1985; Meerhoff et al., 2006).

DHM has been reported as an alternative to diel vertical migration (DVM) for decreasing predation risk in shallow lakes, where a hypolimnetic refuge is absent (Lass and Spaak, 2003). In fact, shallow lakes propitiate a higher contact between prey and predator and refuges can be scarcer than in deep ones. The question is how to define shallow lakes, which are separated from deep lakes by an average depth lower than $3 \mathrm{~m}$, according to Scheffer (2004). However, Padisák and Reynolds (2003) argue that the question is much more complex and beyond the establishment of an arbitrary depth and shallow lakes are polymictic and not seasonally stratified in contrast to deep ones, among other features. In tropical lakes, owing to higher solar radiation, influencing mainly the minimum annual irradiance, small differences in the usually high temperatures lead to stratification for variable periods, whose stability is lower than in temperate lakes (Lewis, 1996).

In Brazilian freshwaters, including Amazonian ones, the predominance of fish guilds other than planktivore and the littoral occupation by most fish species (Arcifa and Northcote, 1997; Arcifa and Meschiatti, 1996; Meschiatti and Arcifa, 2002) lead to the dominance of invertebrate predators in the limnetic zone. Predation pressure can last longer in the tropics because the reproduction of invertebrate predators, such as Chaoborus, can extend for the whole year (e.g. Lewis, 1975; Cressa and Lewis, 1984; Hare and Carter, 1986; Arcifa, 1997). Relatively to temperate lakes, those located in lower latitudes can have a longer regulation period of pelagic zooplanktonic crustacean by predators due to a longer growing season, which can be observed when comparing several lakes (Saunders et al., 1999).

This study has been carried out in a shallow tropical lake that stratifies for variable periods under the influence of predictable and unpredictable climatic factors, and belongs to the warm discontinuous polymictic type (Arcifa et al., 1990).

The present study aimed at evaluating the horizontal distribution of microcrustaceans (cladocerans and copepods) and invertebrate predators, the dipteran Chaoborus brasiliensis and the water mite Krendowskia sp., over a year, focusing on the occurrence of DHM as an alternative to DVM for decreasing predation risk. The study has been driven by the main question: Do planktonic microcrustaceans undergo diel horizontal migration on a yearly basis, which could be a strategy to decrease predation by both invertebrate predators?

\section{Material and Methods}

\subsection{Study area}

Lake Monte Alegre ( $21^{\circ} 10^{\prime} 04$ " S, $47^{\circ} 51$ ' 28” W) is a small, shallow, eutrophic (Silva, 1999) reservoir located in Ribeirão Preto, State of São Paulo, (area 7 ha, $\mathrm{Z} \max .=5 \mathrm{~m}, \mathrm{z}=2.9 \mathrm{~m}$ ). In this study, we follow some of the criteria of Padisák and Reynolds (2003) for defining Lake Monte Alegre as a shallow lake, i.e., a mean depth lower than $9 \mathrm{~m}$ and a polymictic pattern of circulation.

Situated in southeastern Brazil, at an altitude of $500 \mathrm{~m}$, the lake resulted from damming the Laureano Creek, which belongs to the Pardo River basin, in 1942. It can be more clearly stratified, with a defined thermocline, for variable periods in the warm season, leading to oxygen depletion near the bottom in the deepest area (Arcifa et al., 1990), but not in the littoral. As the outlet is superficial and the dam is not manipulated, the retention time ( $c a .45$ days) is relatively high regarding its area and volume, it functions as a small lake as it is not influenced by the hydraulic currents generated by dam manipulation. Currently, it is ornamental and used for research and teaching. The region has a tropical semi-humid climate, with a defined cool-dry season (May-September) and a warm-wet one (October-April), according to Nimer (1989).

Macrophytes are not abundant and are distributed in discrete stands along the margins, and water hyacinths, Eichhornia azurea Kunth, are predominant (Meschiatti and Arcifa, 2002). Higher densities can be found only in the area of the creek inlet, where the rooted Typha sp., Eichhornia crassipes (Mart.) Solms and E. azurea predominate. The straight shoreline, the lack of bays and the prevailing winds that blow in the main axis are reasons for the low macrophyte development. The margins are protected by dense vegetation composed of trees and grass, exerting little influence on the lake through runoff.

The main predators are larvae of the dipteran Chaoborus brasiliensis (maximum length ca. $7 \mathrm{~mm}$ ), which are omnivores and whose diet changes during the ontogeny, the contribution of microcrustaceans increasing 
in the instars III and IV (Arcifa, 2000; Perticarrari et al., 2004; Castilho-Noll and Arcifa, 2007a). Chaoborid larvae are more abundant in the benthos of the pelagic zone, decreasing towards the littoral (Cleto-Filho and Arcifa, 2006). Less abundant predators are the water mite Krendowskia sp. (maximum length ca. $1.3 \mathrm{~mm}$ ), which also preys on Chaoborus larvae (Cassano et al., 2002), and the pump-filter feeder cichlid fish, the adult Tilapia rendalli (Boulenger), whose diet is mostly composed of phytoplankton, zooplankton being a minor item (Arcifa and Meschiatti, 1993, 1996). Adults of Tilapia (166-245 mm standard length) are mainly limnetic, occupying the 1-4 m layer in the water column (Arcifa and Meschiatti, 1993). They are diurnal, not abundant, spawn in nests built onshore in the warm-wet season, and influence the phytoplankton mostly through nutrient excretion in comparison to grazing (Silva, 2004). Even in higher abundance in mesocosms (1 ind./2.5 $\mathrm{m}^{3}$ ) than in the lake, Tilapia did not lower zooplankton densities (Silva, 2004). Main littoral predators are odonates, found in low abundance within macrophyte stands, fish (Meschiatti and Arcifa, 2002), and notonectids, distributed mostly onshore near the edge of macrophytes.

Surface temperatures range from 19 to $30^{\circ} \mathrm{C}$, conductivity from 47 to $96 \mu \mathrm{S} . \mathrm{cm}^{-1}$, and $\mathrm{pH}$ from 5.5 to 8.0 , during the year.

\subsection{Sampling procedure and laboratory analyses}

Three stations were established on a transect in the lake with the characteristics: A. located $8 \mathrm{~m}$ from the margin and near the edge of a stand of macrophytes (Eichhornia azurea), $1 \mathrm{~m}$ deep; B. distant $23 \mathrm{~m}$ from the margin, $3 \mathrm{~m}$ deep; and C. in the middle of the lake, located $c a .50 \mathrm{~m}$ from the margin, $5 \mathrm{~m}$ deep. Station A represents the littoral zone and $\mathrm{B}$ and $\mathrm{C}$ the limnetic zone.

In station $\mathrm{A}$, the width of the macrophyte stand was irregular, reaching a maximum distance of $7.5 \mathrm{~m}$ from the lake edge, and samples were caught at a distance of $8 \mathrm{~m}$, where the depth $(1 \mathrm{~m})$ was adequate for using the pump. As planktonic microcrustaceans were previously caught only near the edge of macrophytes, but not within the stands, where macrophyte-associated species dominated (Meschiatti and Arcifa, 2002), littoral samples were taken near the boundary zone between the macrophyte stand and the open zone in this study.

Monthly samples were taken, at 15 and 21 hours, during a year, from August 2001 to July 2002, for microcrustaceans, chaoborid larvae and water mite. Previous samplings taken four times $(9,15,21$, and 3 hours) indicated that 15 and 21 hours were representative of day and night samples. Two replicate samples $(90 \mathrm{~L}$ each) were taken in the entire water column with a bilge pump (Jabsco, model 34600-0000), delivering $30 \mathrm{~L} . \mathrm{min}^{-1}$, in each station. The water was filtered through a $60 \mu \mathrm{m}$ meshed net and the organisms were fixed in sugared $4 \%$ formalin (Haney and Hall, 1973).

Several sub-samples of $1,2.5$ or $5 \mathrm{~mL}$, taken with Stempel pipettes, were counted for attaining more than 60 individuals in each one, according to McCauley (1984) in order to maintain a coefficient of variation lower than 0.20. Samples with low densities, larvae of Chaoborus brasiliensis, and the water mite Krendowskia sp. were fully counted.

Temperature, dissolved oxygen (DO), electrical conductivity at $25^{\circ} \mathrm{C}, \mathrm{pH}$, and light intensity were measured during zooplankton samplings, using the Yellow Springs Inc. models 95, 30, 60 equipment and the LI 250 photometer respectively. Chlorophyll $a$ was evaluated according to Lorenzen's method (1967) in samples taken in the entire water column. Data were converted to carbon, assuming that chlorophyll is on average $1.25 \%$ of the algae dry weight, and $\mathrm{C}$ is $50 \%$ of the dry weight, within the range given by Reynolds (1984).

\subsection{Data analysis}

Data for each species and chlorophyll from the samples of the whole year were pooled, separately for each period of the day, and tested for differences at day and nighttime and among the three stations, using the Friedman test (significance level $\mathrm{p} \leq 0.05$ ) and the Systat 9.0 program.

\section{Results}

\subsection{Physical, chemical, and biological factors}

Thermal stratification, in the deepest station C, followed the usual pattern of the lake, with episodes of more stable stratification during the summer, when the temperature ranged from 25 to $29^{\circ} \mathrm{C}$, in the water column. The thermocline was located from 2 to $4 \mathrm{~m}$ and dissolved oxygen (DO) concentrations declined to values below $1 \mathrm{mg} . \mathrm{L}^{-1}$, in the narrow hypolimnion (4-5 m), reaching up to $9 \mathrm{mg} \cdot \mathrm{L}^{-1}$ in the upper layer.

In the stations $\mathrm{A}$ and $\mathrm{B}$, the average temperature and DO concentrations, in the water column, varied from 23.4 to $26.4{ }^{\circ} \mathrm{C}$ and 4 to $7 \mathrm{mg} . \mathrm{L}^{-1}$, respectively, during the year. In the deepest station $\mathrm{C}$, the temperature ranged from 20 to $29{ }^{\circ} \mathrm{C}$ and DO from 0.5 to $12.5 \mathrm{mg} . \mathrm{L}^{-1}$, in the water column during the year. Average conductivity, in the water column, varied from $62 \mu \mathrm{S} . \mathrm{cm}^{-1}$ (station A) to

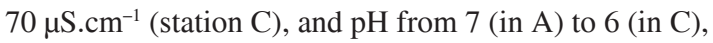
throughout the year.

Chlorophyll $a$ concentrations (Figure 1) were significantly higher $(\mathrm{p}=0.001)$ in $\mathrm{B}$ and $\mathrm{C}$ than in $\mathrm{A}$, during the day. The estimated average algal carbon during the year in the three stations were ca. $0.4,0.5$, and $0.6 \mathrm{mgC} . \mathrm{L}^{-1}$, respectively in $\mathrm{A}, \mathrm{B}$, and $\mathrm{C}$.

The extension of the euphotic zone was variable, light penetrating to the bottom in most dates in $\mathrm{A}$ and $\mathrm{B}$, but only in August and October in C.

\subsection{Horizontal distribution of predators and microcrustaceans}

Owing to high density fluctuations, the distribution of the populations of microcrustaceans were unequally evaluated along the year, as some of them appeared only for a short time in the lake. 
Months

$\mu \mathrm{g} / \mathrm{L}$

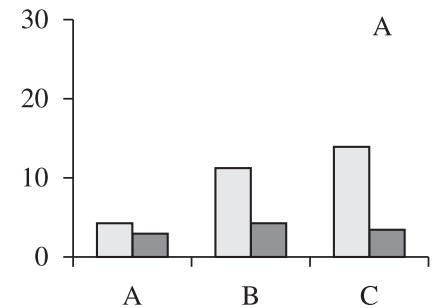

A

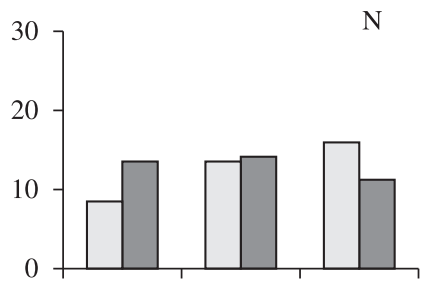

A $B$

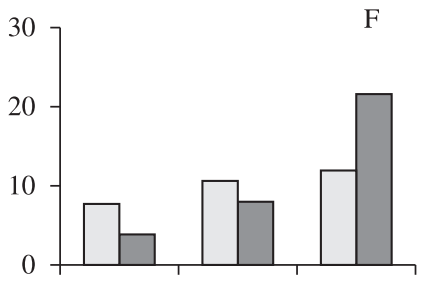

A $B$

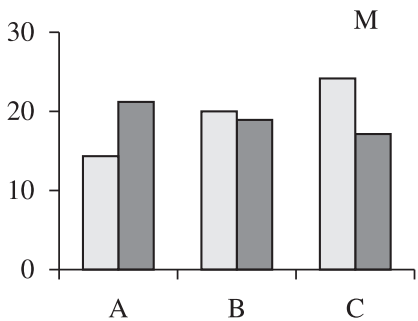

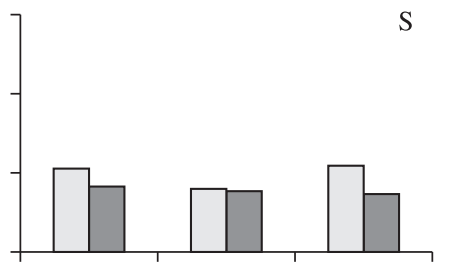

A

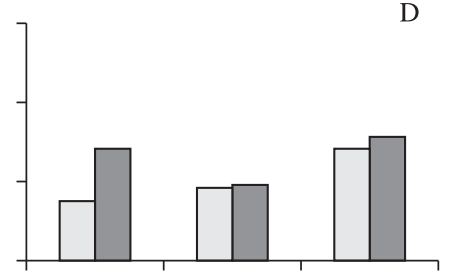

A

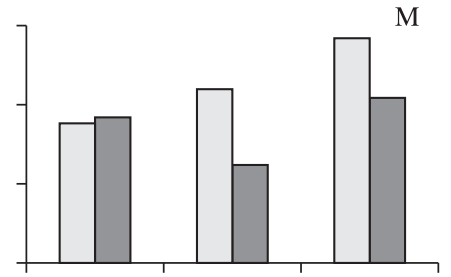

A

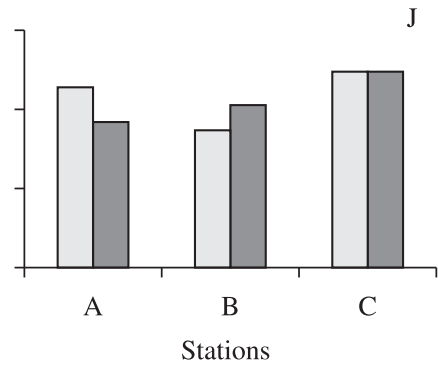

$\square$ Day $\square$ Night
$\mathrm{O}$

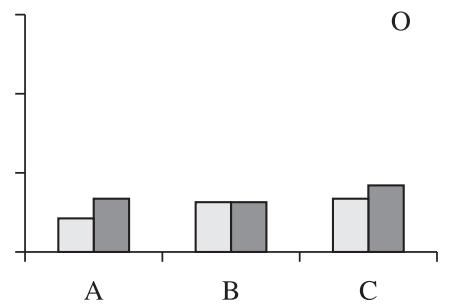

A

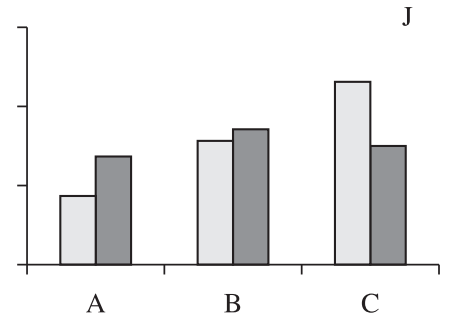

A
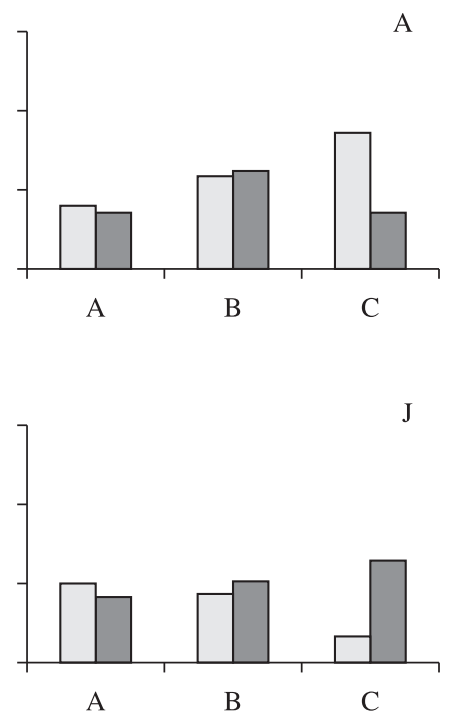

A

C

Figure 1. Day and night distribution of chlorophyll $a$ concentrations, in $\mu \mathrm{g} . \mathrm{L}^{-1}$, in the stations A, B, and C, from August 2001 to July 2002.

Instars III and IV of Chaoborus were mostly pelagic, predominating in $\mathrm{B}$ and $\mathrm{C}$, day and night, and were more abundant at night than during the day, in the water column (Figure 2). Densities were significantly higher in $\mathrm{C}$ than in $\mathrm{B}$ and in $\mathrm{B}$ than in $\mathrm{A}(\mathrm{p}=0.001$ for both) in the daytime. At night, their abundance was also higher in $\mathrm{B}$ and $\mathrm{C}$ than in $A(p=0.001)$. Water mites were essentially pelagic, almost disappearing from the water column during the day, the densities being higher in $\mathrm{C}$ than in $\mathrm{A}$ and $\mathrm{B}$ at night $(\mathrm{p}=0.003)$ (Figure 2).
Densities of Daphnia ambigua Scourfield were significantly higher in $\mathrm{C}$ than in B and in B than in A ( $p=0.001$ for both) during the day (Figure 3). At night, the values were also higher in $\mathrm{B}$ and $\mathrm{C}$ than in $\mathrm{A}(\mathrm{p}=0.02)$. There was no statistical difference in the densities of Daphnia gessneri Herbst among stations in the whole period, but it showed a tendency to be more abundant in the limnetic zone (Figure 3). Significant higher densities ( $p=0.045$ ) of Ceriodaphnia cornuta Sars occurred in C than in A, during the day (Figure 4). There was no statistical 
Ind./L A

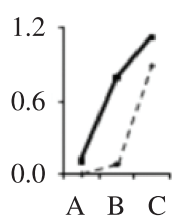

$\mathrm{F}$

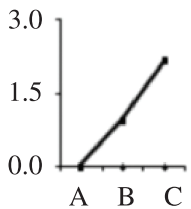

S

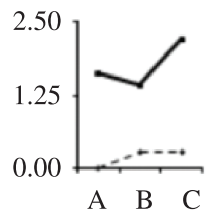

M

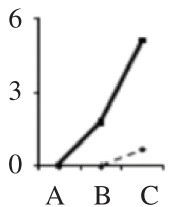

$\mathrm{O}$

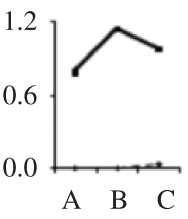

A

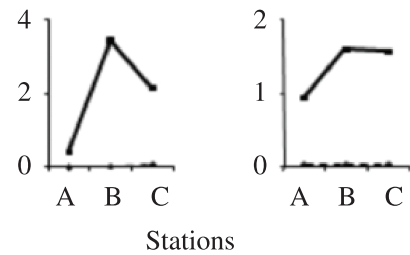

Krendowskia sp.
$\mathrm{N}$

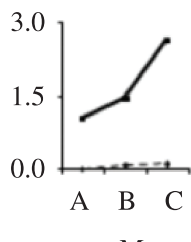

M
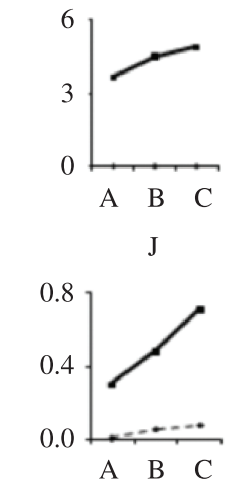

J

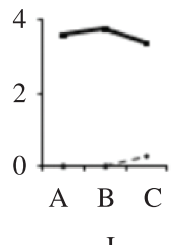

$\mathrm{J}$

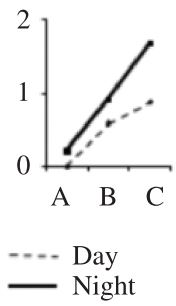

Months

Ind./L A

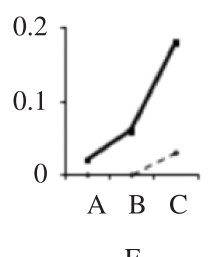

F

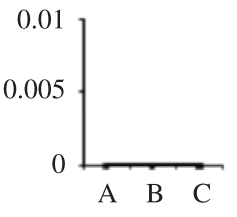

S

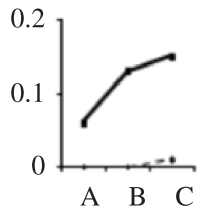

M

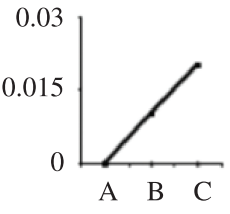

O

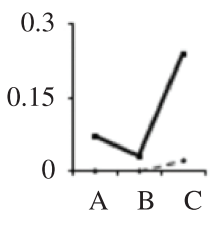

A

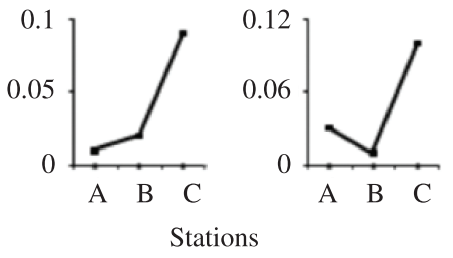

$\mathrm{N}$

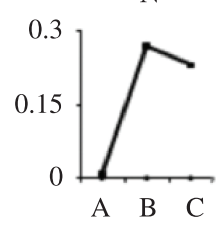

M
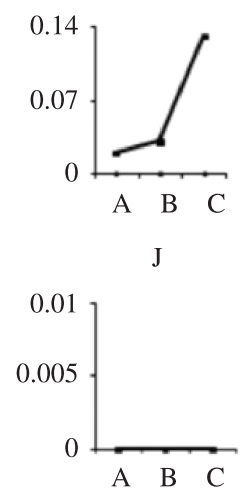
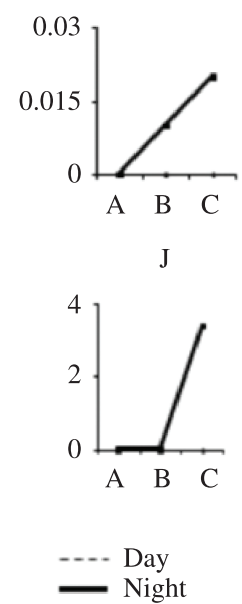

Figure 2. Day and night densities of Chaoborus larvae III and IV and the water mite Krendowskia sp., in the stations A, B, and C, from August 2001 to July 2002.

difference in the distribution of Ceriodaphnia richardi Sars in the three stations, considering the whole period (Figure 4). Although there was no significant difference in the horizontal distribution of Bosmina tubicen Brehm (Figure 5), its occupation of station A on several dates was more effective than those by other cladocerans.

The densities of nauplii and copepodites of both copepod species were significantly higher $(\mathrm{p}=0.001)$ in B and C (Figure 6), as well as those of adults of Tropocyclops prasinus meridionalis $(\mathrm{p}=0.001)$ (Figure 7). There was no significant difference among stations for adults of
Thermocyclops decipiens Kiefer, which on a few occasions tended to be located onshore.

\section{Discussion}

Diel horizontal migration was not performed by microcrustaceans throughout the year in Lake Monte Alegre, as was also found in a short-term study on both DHM and DVM (A. Perticarrari et al., unpublished). The planktonic species were either indistinctly distributed in the three stations or preferentially located in the pelagic zone, where the invertebrate predators, chaoborids and 


\section{D. ambigua}

Months

Ind./L A
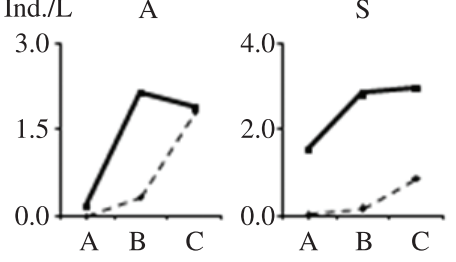

F

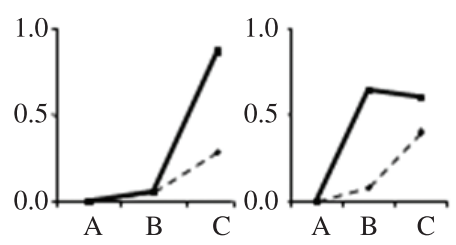

$\mathrm{O}$

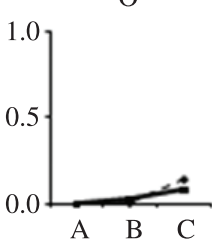

A

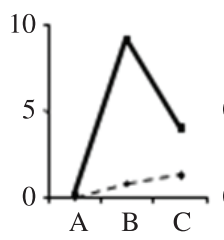

D

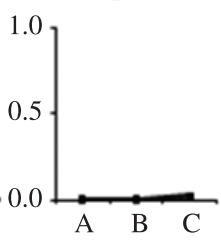

J
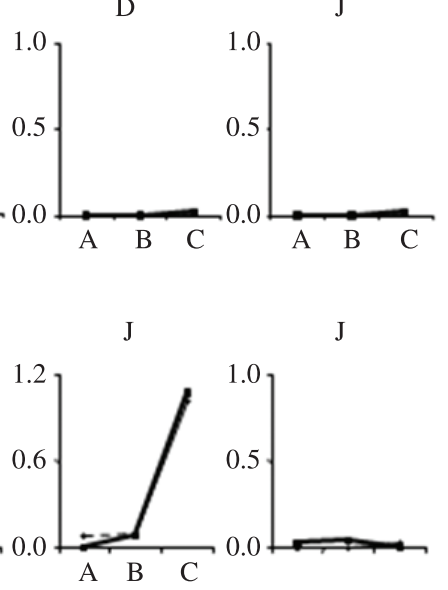

Stations

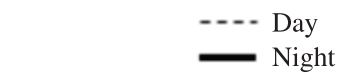

\section{D. gessneri}

Months

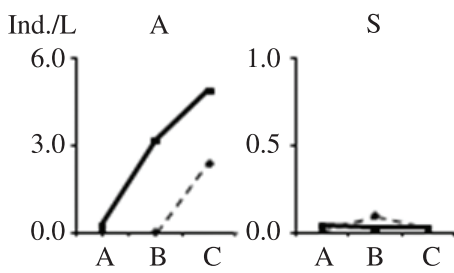

O

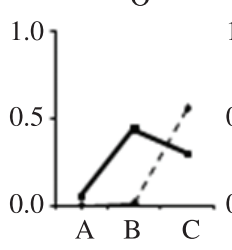

N

D

M

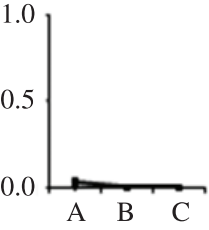

M

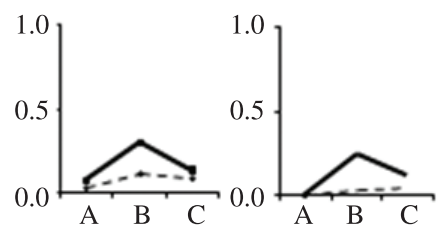

A

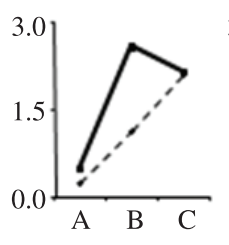

M

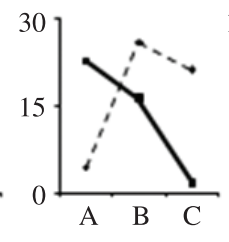

Stations
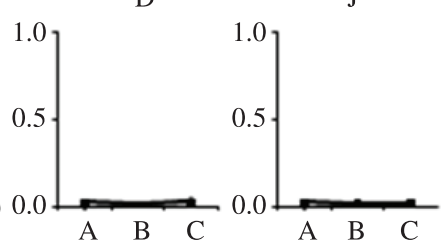

J

J
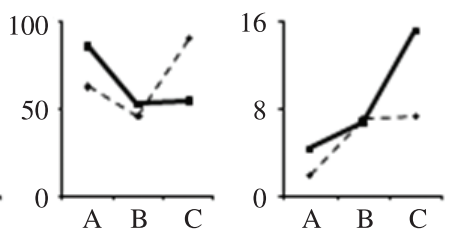

-.-. Day

Figure 3. Day and night densities of Daphnia ambigua and D. gessneri, in the stations A, B, and C, from August 2001 to July 2002.

mites, are more abundant. Higher population densities of microcrustaceans were occasionally found in the littoral.

The limnological features, temperature, DO concentrations, $\mathrm{pH}$, and conductivity, indicate that the conditions in the littoral were suitable for the organisms and did not impair the displacement to that zone. Low DO concentrations in the hypolimnion, during the warm season, in the pelagic zone, certainly limited the vertical distribution of the organisms, but did not interfere in the horizontal distribution. Carbon concentrations were not so low in the littoral compared to the limnetic zone, but the quality of the food resource was not evaluated and, therefore, it is not possible to discuss its influence on the distribution of the organisms. 
C. richardi

Months

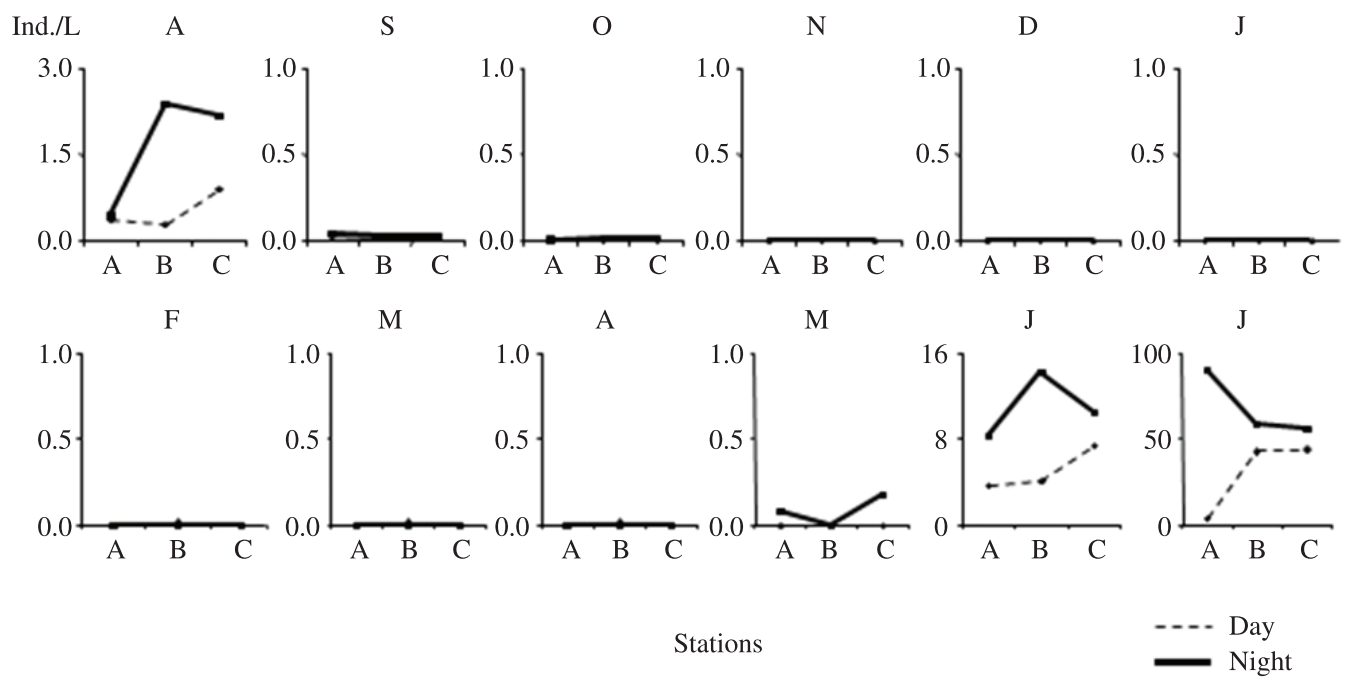

C. cornuta

Months

Ind./L $\quad \mathrm{A}$

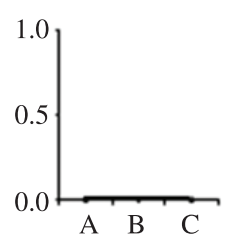

F

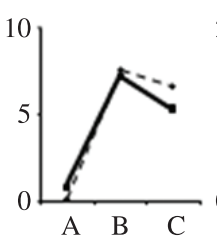

S

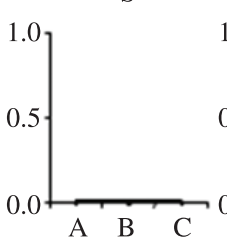

M

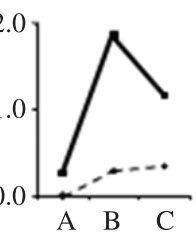

$\mathrm{O}$

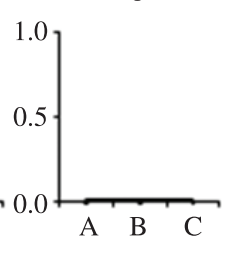

A

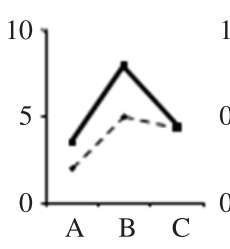

$\mathrm{N}$

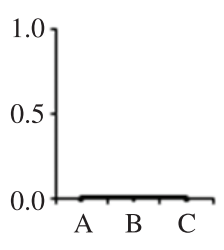

M

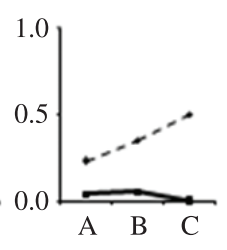

Stations
$\mathrm{D}$
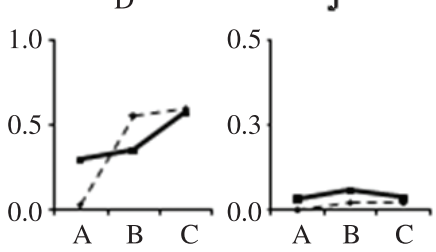

$\mathrm{J}$
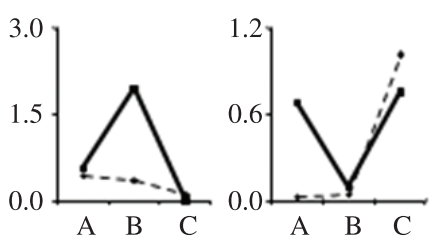

-.-- Day

Figure 4. Day and night densities of Ceriodaphnia cornuta and C. richardi, in the stations A, B, and C, from August 2001 to July 2002.

Performing DHM and seeking refuge in the littoral may constrain most prey and might be the reason for not being adopted as a strategy by microcrustaceans in the Lake Monte Alegre. Within the stands of macrophytes of this lake, the main invertebrate predator, odonates, has low populations in comparison with other organisms, such as chironomids, nematodes, macrophyte-associated microcrustaceans, and oligochaetes (Meschiatti and Arcifa, 2002). However, other potential predators, such as juveniles and adults of most fish species, which are concentrated in the littoral, in macrophytes and the free water nearshore, feed mainly on aquatic insects, but also include zooplankton as a minor dietary item (Arcifa and Meschiatti, 1993; Meschiatti and Arcifa, 2002). As they 
Months

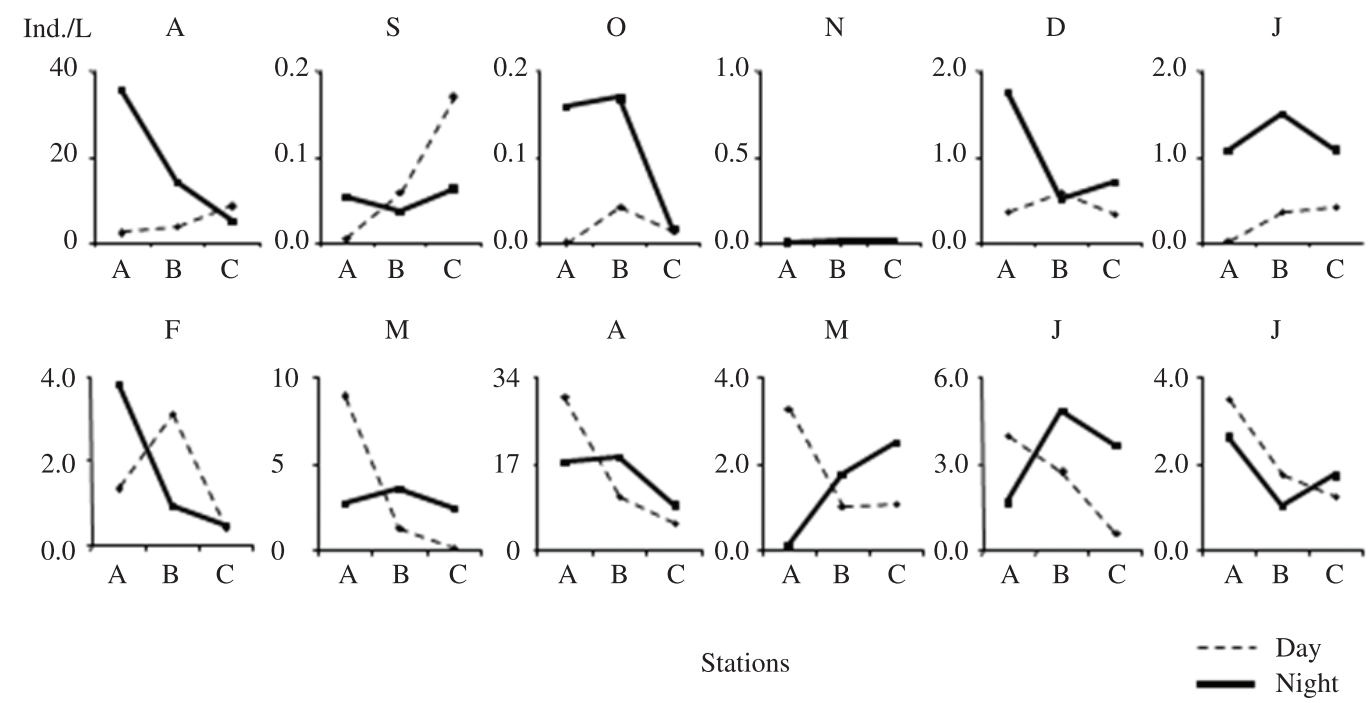

Figure 5. Day and night abundance of Bosmina tubicen, in the stations A, B, and C, from August 2001 to July 2002.

are opportunistic and able to feed on littoral cladocerans (chydorids and macrothricids), a large and visible planktonic microcrustacean might be an attractive prey. Notonectids are potential predators of microcrustaceans nearshore, as they can feed on them (e.g. Murdoch et al., 1984; Hampton et al., 2000), and dive to $50-60 \mathrm{~cm}$ in the water column (Streams, 1992). Although gerrids are known as insectivores (McLean, 1990; Olejniczak et al., 2007), studies in progress on littoral predators in the lake showed in preliminary laboratory experiments that they can prey on cladocerans (M. S. Arcifa et al., unpublished).

The sensitivity to littoral invertebrate predation can differ among organisms. Bosmina and calanoid copepods were more sensitive to littoral invertebrate predators in contrast to cyclopoids, in experiments in a South American lake (González Sagrario et al., 2009). Nevertheless, Bosmina can undergo DHM in some lakes, as in a subtropical Uruguayan lake, where $B$. longirostris performed reverse DHM in spring, probably escaping from chaoborid predation (Iglesias et al., 2007).

In the Lake Monte Alegre, Bosmina tubicen is susceptible to predation by chaoborids in the pelagic zone, as it is the favorite prey (Arcifa, 2000), and possibly by mites, what probably caused its virtual disappearance from the lake (Cassano et al., 2002). This sensitivity seems to be lower in the littoral, where it was preferentially distributed during a short-term study on both DHM and DVM (A. Perticarrari et al., unpublished), which is a trend in this long-term study.

The distribution of young stages and most adults of cyclopoid copepods in the limnetic zone of the lake in closer contact with predators might be adaptive due to their lower susceptibility to pelagic predation than other microcrustaceans. Mites do not prey on them (Cassano et al., 2002), they are avoided by adult Tilapia (Arcifa and Meschiatti, 1996), and despite being preyed on by chaoborid larvae (Castilho-Noll and Arcifa, 2007a), their population dynamics were not significantly affected in the treatment with chaoborids in mesocosms (CastilhoNoll and Arcifa, 2007b).

Food composition can differ in the littoral zone compared to the limnetic one (Smiley and Tessier, 1998), negatively influencing organisms that undergo DHM. In addition to algal food quantity being lower in the littoral in the lake, algal quality may be different. The estimated average algal carbon in the three stations $\left(0.4-0.6 \mathrm{mgC} . \mathrm{L}^{-1}\right)$ are not limiting for some cladocerans in the lake, whose threshold food concentration and the incipient level are, respectively, $<0.025 \mathrm{mgC} . \mathrm{L}^{-1}$ and between 0.1 and $0.2 \mathrm{mgC} . \mathrm{L}^{-1}$ (Bunioto and Arcifa, 2007). Detailed analyses of food quality onshore and offshore are in progress, because laboratory experiments with cladocerans from the Lake Monte Alegre showed lower intrinsic rates of population growth (r) and fecundity of Moina micrura and Ceriodaphnia cornuta in the microplankton fraction (> $20 \mu \mathrm{m})$ (Fileto et al., 2004). This fraction, however, promoted a higher fecundity of the macrophyte-associated cladoceran Simocephalus mixtus. Bosmina longirostris, from a shallow Brazilian lake connected to the Paranapanema River, was unable to reproduce in biossays with the largest phytoplankton fraction (>36 $\mu \mathrm{m}$ ) (Fileto et al., 2010). However, among microcrustaceans, Bosmina and Ceriodaphnia, which can feed on nonalgal resources, are better able to explore the 


\section{Nauplii}

Months

Ind./L $\quad \mathrm{A} \quad \mathrm{S}$

$\mathrm{O}$

$\mathrm{N}$

D

$\mathrm{J}$
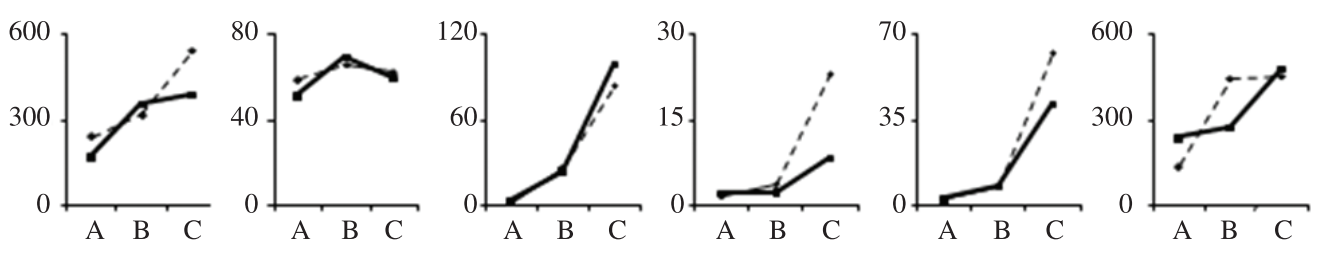

F

M

A

M

$\mathrm{J}$

$\mathrm{J}$
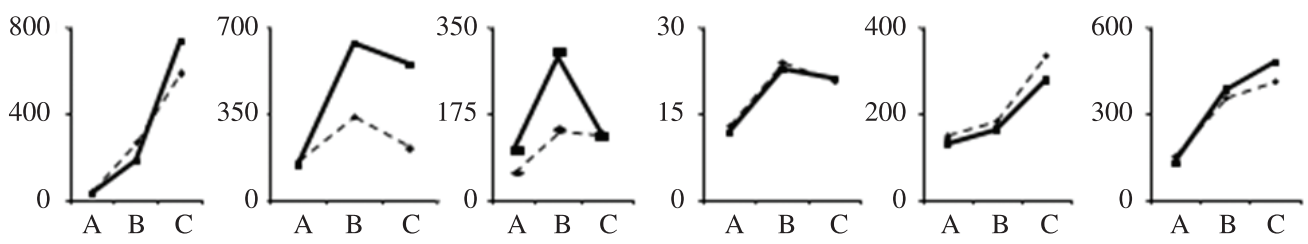

Stations

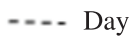

— Night

\section{Copepodites}

Months

Ind./L $\quad \mathrm{A} \quad \mathrm{S}$

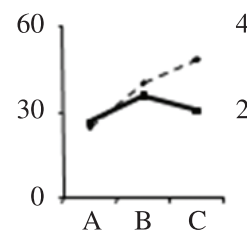

$\mathrm{O}$

$\mathrm{N}$

D

J
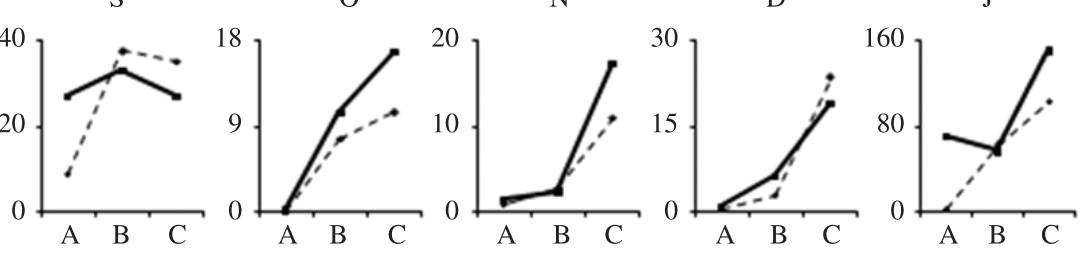

F

A

M
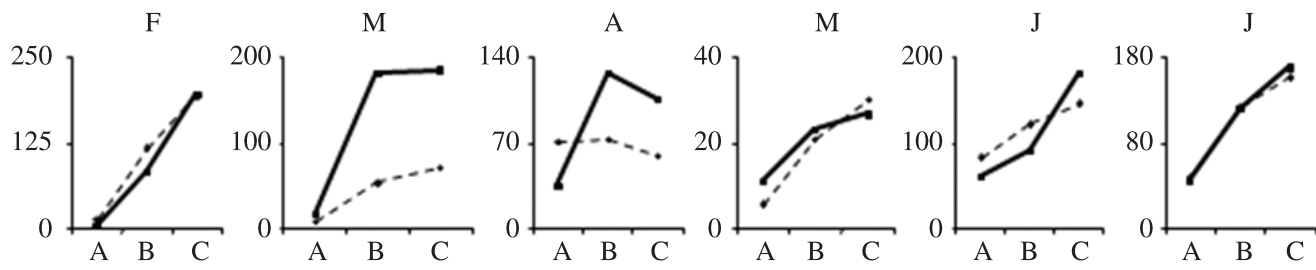

Stations

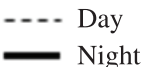

Figure 6. Day and night densities of nauplii and copepodites, in the stations A, B, and C, from August 2001 to July 2002.

littoral where heterotrophic conditions can prevail (Smiley and Tessier, 1998).

We may hypothesize that other behaviors, shown by microcrustaceans in this lake, are more adaptive to cope with predation than DHM. They are the copepod reverse migration (Perticarrari et al., 2004; Minto et al., 2010); the diel location of some cladocerans in the uppermost layers (A. Perticarrari et al., unpublished); aggregations of individuals, DVM and a more superficial location of young Daphnia ambigua and D. gessneri (Perticarrari et al., 2003; Sousa, 2003), which are selectively preyed on by chaoborid larvae (Arcifa, 2000).

In conclusion, microcrustaceans did not undergo significant DHM in the Lake Monte Alegre throughout one year, showing an indistinct distribution in the littoral and the pelagic zone or preference for the latter zone. They 
Months

Ind./L $\quad \mathrm{A}$

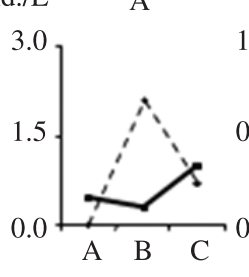

F

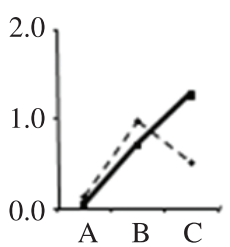

S

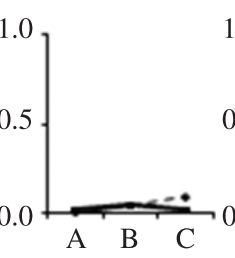

M

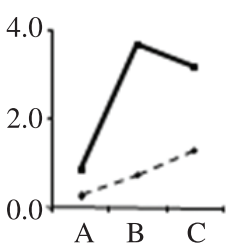

$\mathrm{O}$

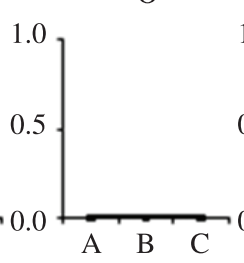

A

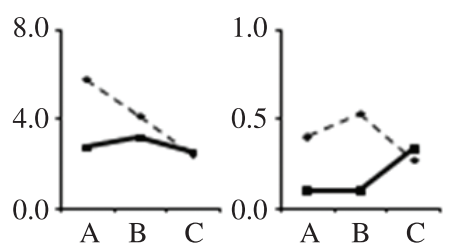

M
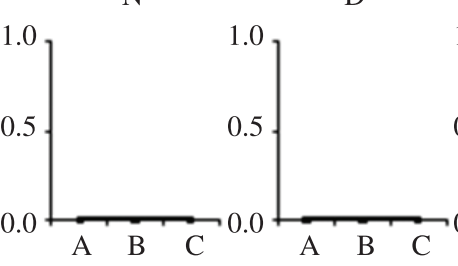

J
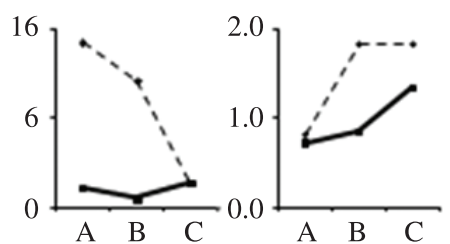

Stations

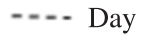

\section{T. prasinus meridionalis}

Months

Ind./L A

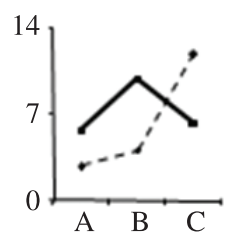

F

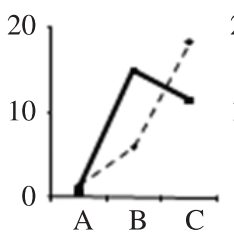

S

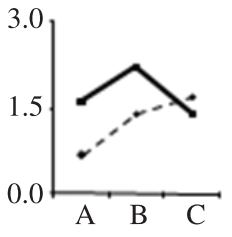

M
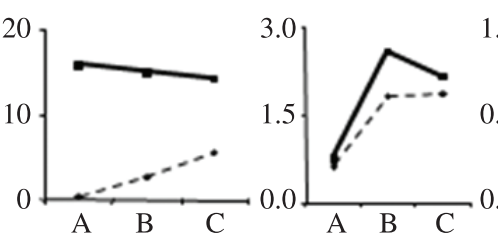

A

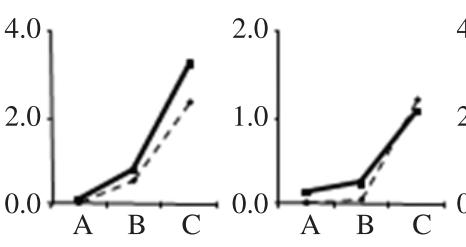

$\mathrm{N}$

D

J

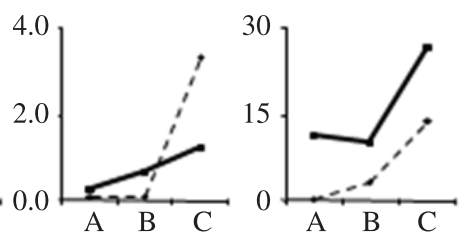

M

J

J

Stations

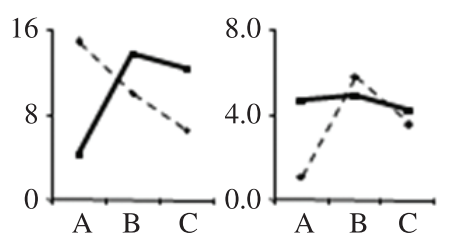

-..- Day

- Night

Figure 7. Day and night densities of adults of Thermocyclops decipiens and Tropocyclops prasinus meridionalis, in the stations A, B, and C, from August 2001 to July 2002.

occasionally occupied the pelagic zone and the littoral on a diel cycle, but not as regular behavior denoting DHM. It seems that seeking the littoral on a diel basis is not the best strategy to escape from limnetic predators, because the risk of predation in the littoral can also be high, besides the possibility of this habitat not meeting the planktonic microcrustaceans' requirements.

Acknowledgements - Special thanks are due to the statistician R. C. dos Santos for the data analyses. We would also like to thank all the people who have helped in the field work and J. A. 
Jorge for the loan of laboratory equipment, and an anonymous reviewer for valuable suggestions. Thanks are due to FAPESP for the financial support to MSA (process 97/10407-6) and grants to TCB (process 01/01150-9) and AP (process 00/12730-3).

\section{References}

ARCIFA, MS., 1997. Fluctuations and vertical migration of Chaoborus in a tropical Brazilian reservoir: Lake Monte Alegre. Acta Limnologica Brasiliensia, vol. 9, p. 93-103.

-, 2000. Feeding habits of Chaoboridae larvae in a tropical Brazilian reservoir. Revista Brasileira de Biologia $=$ Brazilian Journal of Biology, vol. 60, p. 591-597. PMid:11241957.

ARCIFA, MS., MESCHIATTI, AJ. and GOMES, EAT., 1990. Thermal regime and stability of a tropical shallow reservoir: Lake Monte Alegre, Brazil. Revue d'Hydrobiogie tropicale, vol. 23, p. 271-281.

ARCIFA, MS. and MESCHIATTI, AJ., 1993. Distribution and feeding ecology of fishes in a Brazilian reservoir: Lake Monte Alegre. Interciencia, vol. 18, p. 302-313.

-, 1996. Tilapia rendalli in the Lake Monte Alegre, a case of planktivory. Acta Limnologica Brasiliensia, vol. 8, p. 221-229.

ARCIFA, MS. and NORTHCOTE, TG., 1997. Need for holistic approaches in food web experiments and biomanipulation in tropical lakes: A Brazilian reservoir experience. Verhandlungen der Internationale Vereinigung für Limnologie, vol. 26, p. 661-665.

BUNIOTO, TC. and ARCIFA, MS., 2007. Effects of food limitation and temperature on cladocerans from a tropical Brazilian lake. Aquatic Ecology, vol. 41, p. 569-578. http://dx.doi.org/10.1007/ s10452-007-9114-2

BURKS, RL., JEPPESEN, E. and LODGE, DM., 2001. Littoral zone structures as refugia against fish predators. Limnology and Oceanography, vol. 46, p. 230-237. http://dx.doi.org/10.4319/ lo.2001.46.2.0230

BURKS, RL., LODGE, DM., JEPPESEN, E. and LAURIDSEN, TL., 2002. Diel horizontal migration: costs and benefits of inhabiting the littoral. Freshwater Biology, vol. 47, p. 343-365. http://dx.doi.org/10.1046/j.1365-2427.2002.00824.x

CASSANO, CR., CASTILHO-NOLL, MSM. and ARCIFA, MS., 2002. Water mite predation on zooplankton of a tropical lake. Brazilian Journal of Biology, vol. 62, p. 565-571. PMid:12659004. http://dx.doi.org/10.1590/S1519-69842002000400002

CASTILHO-NOLL, MSM. and ARCIFA, MS., 2007a. Chaoborus diet in a tropical lake and predation of microcrustaceans in laboratory experiments. Acta Limnologica Brasiliensia, vol. 19, p. 163-174.

-, 2007b. Mesocosm experiment on the impact of invertebrate predation on zooplankton of a tropical lake. Aquatic Ecology, vol. 41, p. 587-598. http://dx.doi.org/10.1007/s10452-007-9112-4

CLETO-FILHO, SEN. and ARCIFA, MS., 2006. Horizontal distribution and temporal variation of the zoobenthos of a tropical Brazilian lake. Acta Limnologica Brasiliensia, vol. 18, p. 407-421.

CRESSA, C. and LEWIS, WM. Jr., 1984. Growth and development patterns in a tropical Chaoborus species and their ecological significance. Archiv für Hydrobiologie, vol. 100, p. 21-28.

DORGELO, J. and HEYKOOP, M., 1985. Avoidance of macrophytes by Daphnia longispina. Verhandlungen der Internationale Vereinigung für Limnologie, vol. 22, p. 3369-3372.
FILETO, C., ARCIFA, MS., FERRÃO-FILHO, AS. and SILVA, LHS., 2004. Influence of phytoplankton fractions on growth and reproduction of tropical cladocerans. Aquatic Ecology, vol. 38, p. 503-514. http://dx.doi.org/10.1007/s10452-004-4087-x

FILETO, C., ARCIFA, MS., HENRY, R. and FERREIRA, RAR., 2010. Effects of temperature, sestonic algae features, and seston mineral content on cladocerans of a tropical lake. Annales de Limnologie - International Journal of Limnology, vol. 46, p. 135-147. http://dx.doi.org/10.1051/limn/2010007

GONZÁLEZ SAGRARIO, MA., BALSEIRO, E., ITUARTE, R. and SPIVAK, E., 2009. Macrophytes as refuge or risky area for zooplankton: a balance set by littoral predacious macroinvertebrates. Freshwater Biology, vol. 54, p. 1042-1053. http://dx.doi.org/10.1111/ j.1365-2427.2008.02152.x

HAMPTON, SE., GILBERT, JJ. and BURNS, CW., 2000. Direct and indirect effects of juvenile Buenoa macrotibialis (Hemiptera: Notonectidae) on the zooplankton of a shallow pond. Limnology and Oceanography, vol. 45, p. 1006-1012.

HANEY, JF. and HALL, DJ., 1973. Sugar-coated Daphnia: A preservation technique for Cladocera. Limnology and Oceanography, vol. 18, p. 331-333. http://dx.doi.org/10.4319/lo.1973.18.2.0331

HARE, L. and CARTER, JHC., 1986. The benthos of a natural West African lake, with emphasis on the diel migrations and lunar and seasonal periodicities of the Chaoborus populations (Diptera, Chaoboridae). Freshwatater Biology, vol. 16, p. 759-780. http:// dx.doi.org/10.1111/j.1365-2427.1986.tb01016.x

IGLESIAS, C., GOYENOLA, G., MAZZEO, N., MEERHOFF, M., RODÓ, E. and JEPPESEN, E., 2007. Horizontal dynamics of zooplankton in subtropical Lake Blanca (Uruguay) hosting multiple zooplankton predators and aquatic plant refuges. Hydrobiologia, vol. 584, p. 179-189. http://dx.doi.org/10.1007/s10750-007-0599-4

LASS, S. and SPAAK, P., 2003. Chemically induced anti-predator defences in plankton: a review. Archiv für Hydrobiologie, vol. 491, p. 221-239. http://dx.doi.org/10.1023/A:1024487804497

LAURIDSEN, TL. and BUENK, I., 1996. Diel changes in the horizontal distribution of zooplankton in the littoral zone of two shallow eutrophic lakes. Archiv für Hydrobiologie, vol. 137, p. $167-176$

LAURIDSEN, TL., PEDERSEN, LJ., JEPPESEN, E. and SØNDERGAARD, M., 1996. The importance of macrophyte bed size for cladoceran composition and horizontal migration in a shallow lake. Journal of Plankton Research, vol. 18, p. 2283-2294. http://dx.doi.org/10.1093/plankt/18.12.2283

LEWIS, WM. Jr., 1975. Distribution and feeding habits of a tropical Chaoborus population. Verhandlungen der Internationale Vereinigung für Limnologie, vol. 19, p. 3106-3119.

-, 1996. Tropical lakes: how latitude makes a difference: In SCHIEMER, F. and BOLAND, KT. (Eds.). Perspectives in tropical limnology. Amsterdam: SPB Academic Publishing bv. p. 43-64.

LORENZEN, CJ., 1967. Determination of chlorophyll and phaeo-pigments: Spectrophotometric equations. Limnology and Oceanography, vol. 12, p. 343-346. http://dx.doi.org/10.4319/ lo.1967.12.2.0343

McCAULEY, E., 1984. The estimation of the abundance and biomass of zooplankton in samples. In DOWNING, JA. and RIGLER, FH. (Eds.). A Manual on methods for the assessment of secondary productivity in fresh waters. London: IBP Blackwell Scientific Publications. p. 228-265. 
McLEAN, EB., 1990. Sexual dimorphism and predaceous feeding habits of the waterstrider Gerris remigis Say (Heteroptera: Gerridae). Canadian Journal of Zoology, vol. 68, p. 2688-2691. http://dx.doi.org/10.1139/z90-371

MEERHOFF, M., FOSALBA, C., BRUZZONE, C., MAZZEO, N., NOORDOVEN, W. and JEPPESEN, E., 2006. An experimental study of habitat choice by Daphnia: plants signal danger more than refuge in subtropical lakes. Freshwater Biology, vol. 51, p. 1320-1330. http://dx.doi.org/10.1111/j.1365-2427.2006.01574.x

MEERHOFF, M., IGLESIAS, C., MELLO, FT. DE, CLEMENTE, JM., JENSEN, E., LAURIDSEN, TL. and JEPPESEN, E., 2007. Effects of habitat complexity on community structure and predator avoidance behavior of littoral zooplankton in temperate versus subtropical shallow lakes. Freshwater Biology, vol. 53, p. 1009-1021. http://dx.doi.org/10.1111/j.1365-2427.2007.01748.x

MESCHIATTI, AJ. and ARCIFA, MS., 2002. Early life stages of fish and the relationships with zooplankton in a tropical Brazilian reservoir: Lake Monte Alegre. Brazilian Journal of Biology, vol. 62, p. 41-50. PMid:12185922. http://dx.doi.org/10.1590/ S1519-69842002000100006

MINTO, WJ., ARCIFA, MS. and PERTICARRARI, A., 2010. Experiments on the influence of Chaoborus brasiliensis on the diel vertical migration of microcrustaceans from Lake Monte Alegre, Brazil. Brazilian Journal of Biology, vol. 70, p. 25-35. PMid:20231957.

MIRANDA, LE. and HODGES, KB., 2000. Role of aquatic vegetation on hypoxia and sunfish abundance in bays of a eutrophic reservoir. Hydrobiologia, vol. 427, p. 51-57. http:// dx.doi.org/10.1023/A:1003999929094

MURDOCH, WW., SCOTT, MA. and EBSWORTH, P., 1984. Effects of the general predator, Notonecta (Hemiptera) upon a freshwater community. Journal of Animal Ecology, vol. 53, p. 791-808. http://dx.doi.org/10.2307/4660

NIMER, E., 1989. Climatologia do Brasil. 2nd ed. Rio de Janeiro: IBGE. 421 p.

OLEJNICZAK, I., BONIECKI, P., JABLONSKI, P. and SANGDON, L., 2007. Diet of water striders (Gerris lacustris L. 1758) in a rice-field near Seoul, Korea. Journal of Asia-Pacific Entomology, vol. 10, p. 85-88. http://dx.doi.org/10.1016/S1226-8615(08)60336-2

PADISÁK, J. and REYNOLDS, CS., 2003. Shallow lakes: the absolute, the relative, the functional and the pragmatic. Hydrobiologia, vol. 506-509, p. 1-11. http://dx.doi.org/10.1023/ B:HYDR.0000008630.49527.29
PERTICARRARI, A., ARCIFA, MS. and RODRIGUES, RA., 2003. Diel vertical migration of cladocerans in a tropical lake. Nauplius, vol. 11, 15-25.

-, 2004. Diel vertical migration of copepods in a Brazilian lake: a mechanism for decreasing risk of Chaoborus predation? Brazilian Journal of Biology, vol. 64, p. 289-298. PMid:15462303. http:// dx.doi.org/10.1590/S1519-69842004000200015

REYNOLDS, CS., 1984. The ecology of freshwater phytoplankton. Cambridge: Cambridge University Press. 384 p.

SAUNDERS, PA., PORTER, KG. and TAYLOR, BE., 1999. Population dynamics of Daphnia spp. and implications for trophic interaction in a small monomictic lake. Journal of Plankton Research, vol. 21, p. 1823-1845. http://dx.doi.org/10.1093/ plankt/21.10.1823

SCHEFFER, M., 2004. Ecology of shallow lakes. reprinted. Boston: Kluwer Academic Publishers. 357 p.

SILVA, LHS., 1999. Fitoplâncton de um reservatório eutrófico (Lago Monte Alegre), Ribeirão Preto, São Paulo, Brasil. Brazilian Journal of Biology, vol. 59, p. 281-303.

-, 2004. Fitoplâncton de um pequeno reservatório eutrófico (Lago Monte Alegre, Ribeirão Preto, SP): dinâmica temporal e respostas à ação do zooplâncton e peixes. Rio de Janeiro: Universidade Federal do Rio de Janeiro. 219 p. Tese de Doutorado em Ecologia.

SMILEY, EA. and TESSIER, AJ., 1998. Environmental gradients and the horizontal distribution of microcrustaceans in lakes. Freshwater Biology, vol. 39, 397-409. http://dx.doi.org/10.1046/ j.1365-2427.1998.00287.x

SOUSA, MP., 2003. Migração vertical de jovens e adultos dos cladóceros Daphnia ambigua e D. gessneri no Lago Monte Alegre. Ribeirão Preto: Universidade de São Paulo. 51 p. Trabalho de Conclusão de Bacharelado.

STREAMS, FA., 1992. Age-dependent foraging depths of two species of Notonecta (Heteroptera: Notonectidae) breeding together in a small pond. Aquatic Insects, vol. 14, p. 183-191. http://dx.doi.org/10.1080/01650429209361481

WOJTAL, M., FRANKIEWICZ, P., ANDZIAK, M. and ZALEWSKI, M., 2007. The influence of invertebrate predators on Daphnia spatial distribution and survival in laboratory experiments: support for Daphnia horizontal migration in shallow lakes. International Review of Hydrobiology, vol. 92, p. 23-32. http:// dx.doi.org/10.1002/iroh.200610875 